\title{
Neural activity in hypothalamic and genetic obesity
}

\author{
By David A. York, Department of Nutrition, School of Biochemical and \\ Physiological Sciences, Southampton University, Southampton $\mathrm{SO}_{9}{ }_{3} \mathrm{TU}$
}

The function of the hypothalamus as a site for the regulation of food intake was initially recognized from the description of clinical cases in which hyperphagia was associated with hypothalamic damage. Subsequently these observations were extended to experimental animals by the demonstration that electrolytic lesions stereotaxically placed in the ventromedial hypothalamus (VMH) induced hyperphagia and obesity whereas electrolytic lesions placed in the lateral hypothalamus $(\mathrm{LH})$ induced temporary aphagia followed by hypophagia and resulting weight loss. It was from such observations that Stellar (1954) first proposed the 'dual-centre' hypothesis of a ventromedial satiety centre and LH feeding centre. The historical development of this hypothesis has been reviewed previously (Bray \& York, 1971, 1979). In this paper, I shall discuss the mechanisms through which hypothalamic damage may induce obesity and the evidence that similar central defects may be responsible for the genetically inherited forms of obesity found in the obese $(o b / o b)$ mouse and the Zucker fatty $(f a / f a)$ rat. While there are numerous other forms of inherited obesity and other ways of inducing experimental obesity (Bray \& York, I97I; Bray, I 984), this review will concentrate on the hypothalamic electrolytic or knife-cut form of obesity and on the $a b / o b$ and $f a / f a$ obesities as it is to these models that the majority of our information on nervous function in obesity pertain.

It was with the demonstration that VMH damage in weanling rats would induce obesity without hyperphagia (Han et al. 1965) and that VMH damage still caused obesity in pair-fed rats (Han, 1968) that the realization came that the hypothalamus must also control the energy expenditure side of the energy balance equation. Numerous peripheral metabolic changes had been described in VMH obesity (Bray \& York, 1979) but hyperinsulinaemia has been consistently reported in all studies irrespective of the presence or absence of increased food intake. The evidence led Bray \& York (1979) to propose the autonomic hypothesis as a basis for the development of obesity after hypothalamic damage. The hypothesis was that hypothalamic damage led to an imbalance in the autonomic nervous system, sympathetic activity decreasing and parasympathetic activity increasing, leading to an exaggerated cephalic feed-back (Powley, 1977), an increased insulin secretion and reduced thermogenesis, the net result of which was excessive deposition of fat.

The anatomical location of the hypothalamic centres regulating hyperphagia and hyperinsulinaemia are probably separate. Hyperphagia is associated with destruction of the paraventricular nucleus or section of nerve tracts (ventral noradrenergic bundle) terminating in this nucleus and running lateral to the 
ventromedial nucleus (Gold, 1970; Sclafani \& Berner, 1977; Bray \& York, 1979). Hyperinsulinaemia results from destruction of the ventromedial nucleus (Bray et al. 1982). Thus the effects of ventromedial lesions are dependent on the size and location of the damage.

Vagal activity is increased after VMH lesions, possibly as a result of the removal of inhibition on the dorsal motor nucleus of the vagus. Vagotomy reverses or prevents the obesity associated with VMH lesions in ad lib. and pair-fed rats, although the effect may be attenuated in rats fed on a highly palatable diet (Powley \& Opsahl, 1974; Inoue \& Bray, 1977). The acute and chronic hyperinsulinaemia associated with VMH damage also requires an intact vagal input to the endocrine pancreas (Bethoud \& Jeanrenaud, 1979). LH stimulation induces a similar change in vagal tone to that observed after VMH destruction (Ball, 1974).

In contrast to the parasympathetic vagal activity, the activity of sympathetic neurons is reduced after VMH lesions. This conclusion results from studies on physiological processes known to be controlled by the sympathetic activity, using neurophysiological or biochemical techniques. Thus fat mobilization in response to fasting was impaired in VMH-obese rats (Bray \& Nishizawa, 1982). Noradrenaline turnover in brown adipose tissue (BAT), an index of sympathetic drive to that tissue, is reduced in weanling VMH obesity and in adult rats when hyperphagia is prevented. The normal increase in sympathetic activity in response to feeding and decrease in sympathetic activity in response to starvation are abolished (Van der Tuig et al. 1982, 1985; Young \& Landsberg, 1980; Yoshida \& Bray, 1984). The spontaneous activity of efferent sympathetic nerves to BAT was rapidly reduced after acute VMH lesions and VMH-lesioned rats failed to show the normal increase in nerve activity after acute cold-exposure (Niijima et al. 1984). In contrast, acute electrical stimulation of the VMH leads to sustained increases in firing rate in sympathetic fibres (Yoshimatsu et al. 1985) which is expressed by a stimulation of BAT thermogenesis (Perkins et al. 1981; Holt et al. 1985). LH lesions enhance central sympathetic output to the periphery (Yoshida et al. 1983). Thus these recent studies have extended the original suggestion of Ban (1975) that the VMH is predominantly a sympathetic centre and the LH a parasympathetic centre. It is now clear that both medial hypothalamus and LH may each influence the activity of each limb of the autonomic nervous system. A summary of some of the possible controls is shown in Fig. I.

\section{Autonomic function in genetic obesity}

There is considerable evidence to suggest that the gene defects causing obesity in both the $o b / o b$ mouse and fatty $f a / f a$ rats are expressed centrally (see reviews by Bray, 1984; Bray \& York, 1971, 1979), and that an imbalance in the autonomic nervous system is central to the obesity. Although vagotomy does not prevent the obesity in $f a / f a$ rats (Opsahl \& Powley, 1974), the hyperinsulinaemia of 17 -d-old, preobese rats results from excessive vagal stimulation; it is prevented by vagotomy or atropine while vagal nerve stimulation results in excessive insulin secretion (Rohner-Jeanrenaud et al. 1983 ). Sympathetic activity in BAT, but not heart, is 


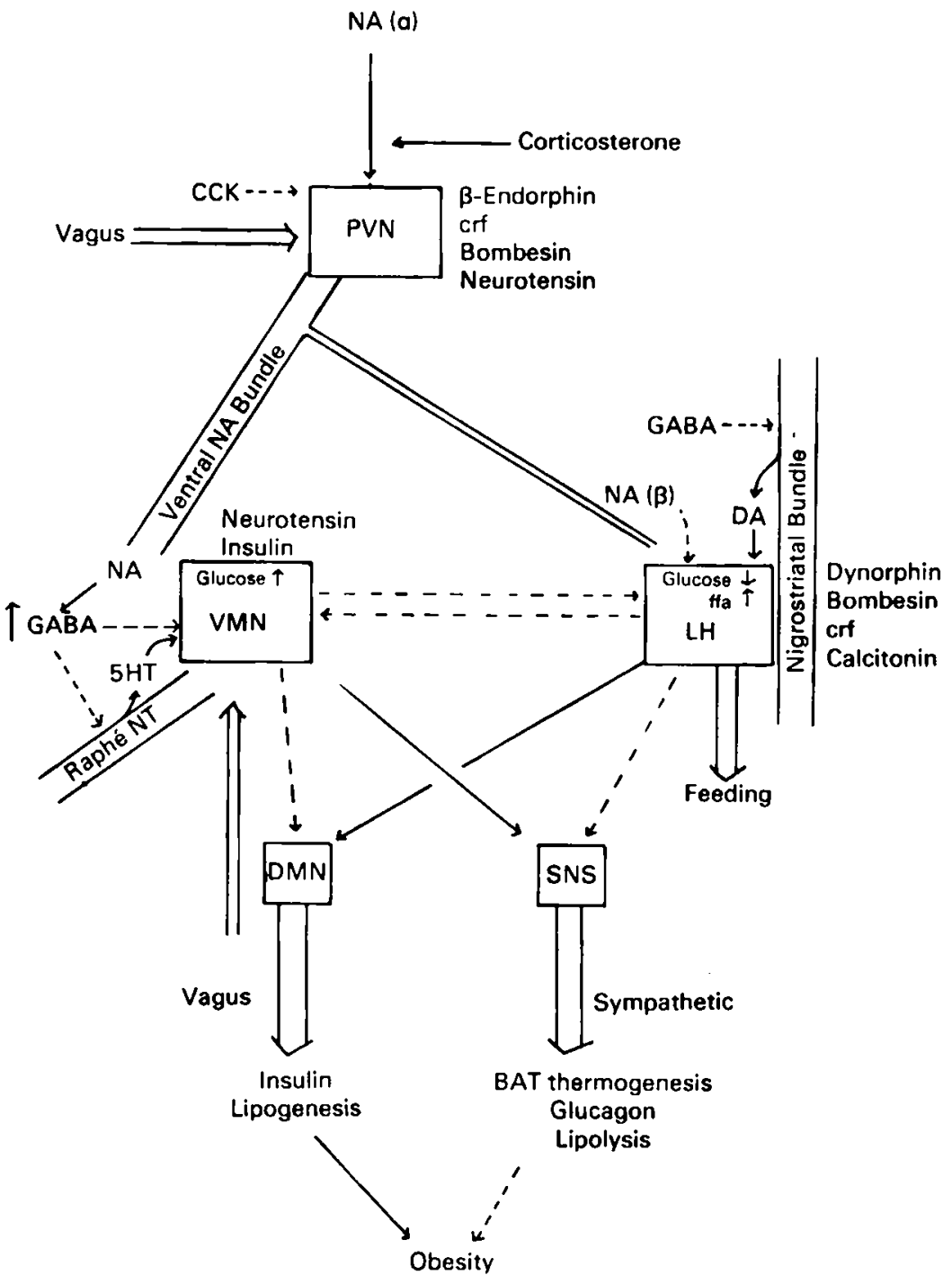

Fig. I. Schematic representation of hypothalamic interactions in the control of food intake and energy balance. ${ }_{5} \mathrm{HT}, 5$-hydroxytryptamine; BAT, brown adipose tissue; ffa, free fatty acids; PVN, paraventricular nucleus; VMN, ventromedial nucleus; LH, lateral hypothalamus; DMN. dorsomotor nucleus; SNS, sympathetic nervous system; NA, noradrenaline; CCK, cholecystokinin; crf, corticotropin-releasing factor; DA, dopamine; GABA, $\gamma$-aminobutyric acid; NT, nuclear tract. $(\longrightarrow)$, Stimulatory influences; $(---\rightarrow)$, inhibitory effects.

reduced as a result of a decrease in central sympathetic drive to the tissue (Levin et al. 1982; Marchington et al. 1983). Similar reduction in sympathetic activity has been reported in the $o b / o b$ mouse (Knehans \& Romsos 1982, 1983; Young \& Landsberg, 1983; Zaror-Behrens \& Himms-Hagen, 1983). The reduction in sympathetic activity in both the $f a / f a$ rat and the $o b / o b$ mouse appears to reflect an inability to respond to dietary signals, since their responses to environmental cold 
remain intact (Knehans \& Rosmos, 1983; Marchington et al. 1983; Young \& Landsberg, 1983; Zaror-Behrens \& Himms-Hagen, 1983). Glucocorticoids impair the central sympathetic response to dietary signals and normal levels of diet-induced sympathetic activity are observed in the $f a / f a$ rat only after adrenalectomy, a procedure which prevents the further development of obesity (Marchington et al. 1983; York et al. 1985).

Both VMH obesity and the genetic obesity of $f a / f a$ and $o b / o b$ genotypes have a number of common characteristics, the most important of which are probably the imbalance between sympathetic and parasympathetic activities and the prevention of the obesity by adrenalectomy (Yukimura \& Bray, 1978; Yukimura et al. 1978; Bray, 1982; Bruce et al. 1982; Marchington et al. 1983). In the genetic obesities, the autonomic imbalance could result from a lack of afferent signals to the brain, a failure to recognize them or a failure to couple them to an appropriate efferent drive. Electrical stimulation of selected hypothalamic regions has shown that the efferent sympathetic pathway to BAT in $f a / f a$ rats is normal (Holt et al. 1985). This research is now directed towards the response of hypothalamic centres to various nutrients and the possible role of glucocorticoids, neurotransmitters and neuropeptides in modulating autonomic balance in these forms of obesity. The possibility of an impairment in central glucose metabolism in the $f a / f a$ rat is discussed later.

\section{Brain morphology and composition}

The brains of both the $o b / o b$ mouse and the $f a / f a$ rat are smaller than those of their respective lean litter-mates in both weight, cortical volume, DNA, sphingomyelin and cerebroside content (Bereiter \& Jeanrenaud, 1979; Van der Kroon \& Speijers, 1979; Saito \& Bray, r 984 ) and some cross-sectional areas of neurons were reduced in eight of the nine brain regions investigated by Bereiter $\&$ Jeanrenaud (1979). LH neurons were of normal dimension, however, whereas the VMH neurons were smaller in the $o b / o b$ mouse, which may be indicative of functional abnormality in the VMH region. However, no genetic differences in dendritic population or branching were observed in the VMH or LH regions, only changes in the orientation of the dendritic fibres (Bereiter \& Jeanrenaud, 1979). As with many of the disorders in genetic and hypothalamic obesity, the reduced brain growth may be corrected by the removal of adrenal glucocorticoids (Saito \& Bray, 1984). The fatty acid composition of brain total lipid and of synaptosomal membrane phospholipids is also altered in $o b / o b$ mice (Hyslop \& York, 1980; Sena et al. 1982). Such changes in membrane composition, which are found in all tissues (York et al. 1982; York, 1985 ), have been implicated in the apparent reduction in $\mathrm{Na}^{+}, \mathrm{K}^{+}-\mathrm{ATP}$ ase units in the brain of $o b / o b$ mice (Hughes \& York, 1983) and may have far-reaching effects on the wide range of membrane-associated events in the brain.

\section{Neuropeptides in obese rats and mice}

In attempting to gain an understanding of the neurochemical basis for altered 
Table 1. Tissue neuropeptide concentrations in rodent obesity

\begin{tabular}{|c|c|c|c|c|}
\hline Neuropeptide & Tissue & $a b / a b$ & $f a / f a$ & VMH \\
\hline$\beta$-Endorphin & $\begin{array}{l}\text { Pituitary } \\
\text { Hypothalamus } \\
\text { Plasma }\end{array}$ & $\frac{1}{1}$ & $\frac{1}{\frac{1}{p t}}$ & 一 \\
\hline Leu-enkephalin & $\begin{array}{l}\text { Brain } \\
\text { Pituitary }\end{array}$ & $\bar{\uparrow}$ & - & \\
\hline Cholecystokinin & Brain & + & - & - \\
\hline Somatostatin & $\begin{array}{l}\text { Hypothalamus } \\
\text { Pituitary }\end{array}$ & & $\begin{array}{c}i t \\
1\end{array}$ & \\
\hline Bombesin & Brain & - & & \\
\hline Neurotensin & Brain & - & & \\
\hline Insulin & $\begin{array}{l}\text { Brain } \\
\text { Hypothalamus }\end{array}$ & & $\downarrow$ & \\
\hline$\beta$-Cell tropin & Pituitary & $\uparrow$ & & \\
\hline
\end{tabular}

$\uparrow$, Increased; $\downarrow$, decreased; - , no change compared to lean litter-mates; VMH, ventromedial hypothalamus

brain function in the genetic obesities, a number of laboratories have directed their attention to studies of neuropeptides and other neurotransmitters. A wide range of neuropeptides have now been identified, many of which are thought to have a physiological role in the central regulation of feeding, appetite, satiety and energy balance. These functions have been reviewed in this symposium (Dockray, 1987) and a number of other excellent reviews (Morley, 1980; Brown, 198I; Morley \& Levine, 1983). Morley \& Levine (1983) have suggested that the endogenous opioids might be responsible for a tonic signal which causes the feeding drive, while other neuropeptides might have a principally inhibitory role in feeding, these controls being integrated mainly in the hypothalamus. There have been numerous reports of regional neuropeptide concentrations in the brains of obese animals (see Table $\mathrm{I}$ ) but there has been little detailed research on neuropeptide concentration in specific nuclei or on neuropeptide receptor characteristics and distribution. Margules et al. (1978) initially made the suggestion that excessive production and secretion of $\beta$-endorphin might cause the hyperphagia of obese $a b / o b$ mice and obese $f a / f a$ rats after showing that pituitary $\beta$-endorphin concentrations were increased in these obese rodents and that naloxone, an opiate antagonist, selectively inhibited the characteristic hyperphagia of the obese genotypes. Subsequent reports have confirmed the increase in pituitary $\beta$-endorphin concentration and have also shown raised plasma levels (Rossier et al. 1979; Govoni \& Yang, 198I). However, these changes may be sex-dependent (Govoni \& Yang, 1981) and may be secondary to the development of the obese state (Rossier et al. 1979; Recant et al. 1980). Hypothalamic $\beta$-endorphin and leu-enkephalin concentrations were, however, normal in the $o b / o b$ mouse and $f a / f a$ rat (Margules 
Table. $2 \beta$-endorphin concentrations (pmol/mg protein) in the pituitary and hypothalamus of obese $(\mathrm{fa} / \mathrm{fa})$ and lean $(\mathrm{Fa} / \mathrm{l})$ rats

\begin{tabular}{|c|c|c|c|c|c|c|c|c|c|}
\hline \multirow[b]{3}{*}{ Age (d) } & \multirow[b]{3}{*}{$n$} & \multicolumn{4}{|c|}{ Pituitary } & \multicolumn{4}{|c|}{ Hypothalamus } \\
\hline & & \multicolumn{2}{|c|}{$f a / f a$} & \multicolumn{2}{|c|}{$\mathrm{Fa} / \mathrm{g}$} & \multicolumn{2}{|c|}{$f a / f a$} & \multicolumn{2}{|c|}{$\mathrm{Fa} / ?$} \\
\hline & & Mean & SEM & Mean & SEM & Mean & SEM & Mean & SEM \\
\hline 20 & Io & 125 & $17 \cdot 5$ & $116 \cdot 3$ & $22 \cdot 3$ & I. $20^{\circ \cdots *}$ & 0.21 & I 79 & 0.05 \\
\hline 28 & 6 & $48 \cdot 8$ & 2.2 & 45.8 & $2 \cdot 9$ & I. 55 & 0.16 & I. 54 & 0.10 \\
\hline $5^{6}$ & 6 & $76 \cdot 2 * 4$ & $5 \cdot$ I & 104.2 & $6 \cdot 2$ & 1.00 & 0.15 & 0.98 & 0.06 \\
\hline
\end{tabular}

Values were significantly different from those for lean litter-mates: $* P<0.01, \cdots * P<0.001$.

et al. 1978). Furthermore, the increase in plasma and pituitary $\beta$-endorphin concentration in the $f a / f a$ rat (Margules et al. 1978; Recant et al. 1983) has not been confirmed in other studies (Govoni \& Yang, 1981; McLaughlin \& Baile, 1985). Our own studies (Table 2) suggest that these differing results might reflect age-dependent changes in $\beta$-endorphin concentration. The increase in pituitary $\beta$-endorphin concentration in the $f a / f a$ rat was observed at 8 weeks of age but not at either $20 \mathrm{~d}$ (preweaning) or $28 \mathrm{~d}$ (weaned) of age. In contrast, hypothalamic $\beta$-endorphin concentration was reduced in the preweaned but normal in the weaned $f a / f a$ rats.

The medial hypothalamus has a high concentration of opioid receptors and $\beta$-endorphin injection into this region will induce feeding. Although increased brain $\beta$-endorphin is associated with feeding, elevated plasma $\beta$-endorphin has been associated with satiety (McLaughlin \& Baile, 1985). However, after VMH lesions in adult rats both pituitary and plasma $\beta$-endorphin concentrations-are increased and food intake enhanced (Matsumura et al. 1984). The strongest evidence for a role of $\beta$-endorphin in the development of obesity has probably come from studies with the antagonists naloxone and naltrexone which bind to the $\mathrm{Mu}$ and kappa receptors. Chronic treatment of both $o b / o b$ mice or obese/SHR rats with these inhibitors reduced food intake and insulin secretion and either attenuated weight gain or, in the latter case, led to a spectacular weight loss (Recant et al. 1980; Wexler \& McMurty, 1985). The locus of this effect is unclear but it is unlikely to be in the VMH since an increased sensitivity to the anorectic effects of naloxone has also been observed in VMH obesity in one study (King et al. 1979) but not in a second study (Gunion \& Peters, 198I). It is probable that the weight loss associated with these endorphin antagonists may not be explicable entirely by their anorectic effect since we (D. A. York and J. Allars, unpublished results) have recently shown that brown adipose tissue thermogenesis is increased acutely in $f a / f a$ rats by naloxone despite the reduction in food intake. A physiological role of $\beta$-endorphin in thermoregulation has been suggested (Gordon et al. 1984 ) but its actions vary according to dose, injection site, species and ambient temperature. 
There is little evidence to suggest that the described changes in $\beta$-endorphin concentrations in the hypothalamus and pituitary of the obese rodents are anything but a secondary response to the developing obesity. However, the increased sensitivity to opiate antagonists in the genetic obesities are a consistent observation and may be of particular importance since it may occur before the deposition of excessive body fat (McLaughlin \& Baile, 1984). As $\beta$-endorphins may regulate neuronal activity (Gordon \& Heath, 1981) a change in sensitivity to opioids might have a major influence on central nervous systems regulating food intake and energy balance. Other peptides, in addition to $\beta$-endorphin, that are derived from the proopiomelanocortin (POMC) precursor protein, are also present in abnormal amounts in the pituitaries of $o b / o b$ mice. The increases in plasma insulin and corticosterone in the $o b / o b$ mouse may result from the increases in pituitary $\beta$-cell tropin (CLIP) and ACTH concentrations respectively (Dunmore \& Beloff-Chain, 1982). In view of the glucocorticoid dependence of the obesity of both $o b / o b$ mice and $f a / f a$ rats, further work on the regulation of POMC production and processing in these obese syndromes is warranted.

Cholecystokinin (CCK) is secreted into the circulation after feeding and will reduce food intake in animals and man when administered exogenously. Specific receptors for CCK (Woods et al. I98I) have been demonstrated in the hypothalamus and CCK binding to these receptors varies with nutritional state (Saito et al. 1981). Initial observations on the $o b / o b$ mouse suggested that brain CCK-8 (the active octapeptide of CCK) concentration was reduced (Strauss \& Yallow, 1979) but subsequent findings suggest both a normal tissue concentration and distribution in the brains of $o b / o b$, gold-thioglucose and Yellow $\left(\mathrm{A}^{\mathrm{y}}\right)$ obese mice and in $f a / f a$ rats (Hansky \& Ho, r979; Finkelstein \& Steggles, I98I; Oku et al. 1984). The impaired responses to the anorectic effects of CCK reported in genetically obese rodents fed on a normal chow but not a highly palatable diet are not observed in VMH-obese rats (Kulkosky et al. 1976; McLaughlin \& Baile, 1978, 1980, 198I; Schneider et al. 1979; Woods et al. 1981). Similarly, bombesin and neurotensin (NTS) brain concentrations and regional distribution appear to be normal in the $a b / o b$ mouse, although NTS receptor numbers were significantly depressed in two regions known to influence body temperature (Rostene $e t$ al. 1985; Sheppard et al. 1985). Microinjection of neurotensin onto the ventromedial nucleus has recently been shown to cause a dose-dependent fall in food intake (Hawkins, 1986). Conflicting evidence of changes in hypothalamic somatostatin concentrations (increased or decreased) have also been reported in obese $a b / a b$ and diabetic $o b / o b$ mice (Patel et al. 1977; Voyles et al. 1982).

The recent demonstration of insulin in the brain and cerebrospinal fluid has led to the suggestion that insulin may provide a feedback signal for the suppression of food intake (Porte \& Woods, $198 \mathrm{r}$ ). Brain insulin content was reduced in $f a / f a$ rats, this reduction being particularly prominent in the hypothalamus and olfactory bulb regions, two regions recognized to function in the centre of energy balance (Baskin et al. 1985). The decrease in insulin content may reflect a reduction in the number of insulin receptors in these areas (Figlewicz et al. 1985) and is of particular 
significance since the reduction in receptor number was gene-dosage dependent and did not appear to result from a down-regulation of receptors. Insulinresponsive glucoreceptor cells have been demonstrated in both the VMH and ventrolateral hypothalamic areas (Le Magnen, 1983; Oomura et al. 1978) so that a loss of insulin receptor capacity may help to explain the apparent insensitivity of $\mathrm{fa} / \mathrm{fa}$ rats to the intraventricular or peripheral administration of 2-deoxyglucose (Ikeda et al. 1980; Rothwell \& Stock, 1981). Allars \& York (1986) have shown that peripherally administered 2-deoxyglucose impairs BAT function in normal rats but was ineffective in $f a / f a$ rats. After adrenalectomy, which prevents the further development of obesity (Yukimura \& Bray, 1978; Yukimura et al. 1978: Marchington et al. 1983), the 2-deoxyglucose inhibitory response is restored in the $f a / f a$ rat. It is probable that this 2-deoxyglucose effect is mediated through central inhibition of sympathetic activity (Rappaport et al. 1982). Thus, the reduction in insulin concentration may impair glucose metabolism in the insulin-responsive glucoreceptor cells, resulting in hyperphagia and depressed sympathetic and enhanced parasympathetic drive in the $f a / f a$ rat. This might explain the lack of response to the glucoprivic actions of 2-deoxyglucose on food intake and BAT function. Adrenalectomy, it is proposed, would restore insulin receptor capacity and enhance glucose metabolism, inducing normal satiety responses, rectifying the autonomic balance and restoring the response to 2-deoxyglucose.

In contrast to insulin, the possible functional significance of the other changes in neuropeptide concentrations and function which have been described are more difficult to interpret, particularly in the light of the changes in brain size and morphology. However, the central regulation of localized neuropeptide receptor populations may provide a mechanism for changing sensitivity to neuropeptides and inducing obesity.

\section{Neurotransmitters}

The relation of the neuropeptide changes in obese animals to other transmitter activity has not been thoroughly investigated. $\gamma$-Aminobutyric acid (GABA) may be a transmitter in the neural circuits of the medial and basolateral hypothalamus which induce satiety (Kimura \& Kuriyama, 1975; Cattabeni et al. 1978; Panksepp \& Meeker, 1980). GABA transaminase inhibitors, which increase brain $\gamma$-amino-n-butyric acid (GABA) concentration, block the hyperphagia in both VMH-obese and obese $f a / f a$ rats (Coscina \& Nobrega, 1984) while systemic administration of GABA (20-40 $\mathrm{g} / \mathrm{kg}$ diet) cause a reversible reduction in food intake and body-weight of $o b / o b$ mice (Tews, 1981). The activity of glutamate decarboxylase (EC 4.1.1.15), the enzyme responsible for synthesis of GABA, is decreased in the brains of VMH-obese rats and the magnitude of the decrease has been correlated with the degree of obesity. In contrast GABA concentrations are reported to be unchanged in the hypothalamus of $f a / f a$ rats although GABA synthesis is enhanced (Orosco et al. 1981). These observations are of particular interest since GABA is known to inhibit $\beta$-endorphin secretion, but further 
investigations are required to study the possibility of functional links between changes in $\beta$-endorphins and GABA in the brains of obese rodents.

The monoaminergic neurotransmitters have been shown to have an important role in the control of appetite and feeding (for reviews, see Morley, 1980; Stricker \& Zigmond, 1984). Some aspects of these control systems are summarized in Fig. I. Noradrenaline stimulation of the paraventricular nucleus, an $\alpha$-mediated effect, induces feeding (Liebowitz, I978; Goldman et al. 1985). This effect is glucocorticoid-dependent, a characteristic which may be relevant to the glucocorticoid dependence of the genetic and hypothalamic obesities (Liebowitz et al. 1984; Jhanwar-Uniyal et al. 1985) and may be mediated through a GABA-dependent inhibition of the ventromedial satiety centre. The ventromedial nucleus is closely associated with the ventral noradrenergic bundle. When noradrenaline is depleted from this bundle hyperphagia and weight gain result (Sahabian et al. 1983). In addition the ventromedial satiety centre is itself stimulated by 5 -hydroxytryptamine $\left({ }_{5} \mathrm{HT}\right)$ whose effects are blocked by GABA. The LH feeding drive is inhibited by $\beta$-adrenergic action (Grossman, 1962). This area of the hypothalamus is clearly associated with the nigrostriatal bundle of dopaminergic nerves which have a high density of opiate receptors in their terminals (Pollard et al. 1978). Depletion of dopamine from these nerves mimics the LH aphagia response (Ljunberg \& Ungerstedt, I976), and lesions of the LH which inhibit feeding also damage the nigrostriatal tract and extensively deplete dopamine. It is not surprising, therefore, that considerable attention has been focused on brain monoamine concentrations in genetic obesities.

There is conflicting information on hypothalamic noradrenaline levels in genetic obesities. Whereas Lorden et al. (1975) showed an increase in hypothalamic noradrenaline concentrations in $a b / o b$ mice, no such difference was observed in another study (Nemeroff et al. 1978). Brain noradrenaline turnover and the activities of amine oxidase (flavin-containing) $(E C \quad$ I.4.3.4) and catechol methyltransferase (EC 2.1.1.6) were all unaltered (Lorden et al. 1976; Feldman \& Henderson, 1978). In more definitive studies, a decrease in noradrenaline concentration in the paraventricular nucleus and an increase in the median eminence of $f a / f a$ rats have been reported. Concentrations of noradrenaline in other areas were unaltered (Cruce et al. 1976; Levin \& Sullivan, 1979a). This could reflect an excessive secretion, inducing hyperphagia, since intraventricular noradrenaline induced a normal feeding response in obese rats (Ikeda et al. 1980). Indeed, the activities of a number of enzymes involved in catecholamine biosynthesis were increased in the brains of $f a / f a$ rats (Levin \& Sullivan, 1979b). However, these changes were more pronounced in old $f a / f a$ rats and may be undetectable at younger ages. This, together with the localized nature of some of the reported changes, suggests that the described alterations in noradrenaline concentrations may be a reflection of other events impinging on that area. The noradrenaline-paraventricular response is associated in particular with a stimulation of carbohydrate feeding, whereas $f a / f a$ rats have a preference for dietary fat rather than carbohydrate (Castonguay et al. 1982). Dopamine 
concentrations are also unaltered in both obese mice and rats (Cruce et al. 1976) whereas brain $5 \mathrm{HT}$ levels are elevated in $o b / o b$ mice probably as a result of the increase in serum tryptophan (Garthwaite et al. 1979). There is thus little evidence to connect the hyperphagia of the genetic obesities to changes in brain monoamine levels. However, the obese rodents do show significant changes in sensitivity to a number of anorectic drugs (e.g. amphetamine, fenfluramine) thought to act through effects on the monoaminergic transmitter-receptor systems Garattini \& Samanin, 1984; Silverstone \& Goodall, 1984) suggesting that some aspects of these control systems may be abnormal. Further research is clearly needed and warranted.

\section{Conclusion}

The central control of food intake and automatic function are clearly extremely complex and not well-understood. Further studies on the abnormalities in organization and function of the central nervous system in the genetic obesities and the glucocorticoid dependence of these changes may not only increase our understanding of the central control of energy balance but may also lead to the identification of the protein defect in these inherited syndromes.

\section{REFERENCES}

Allars, J. \& York, D. A. (1986). International fournal of Obesity (In the Press).

Ball, G. G. (1974). Science 184, 484-485.

Ban, T. (1975). Pharmacology, Biochemistry and Behaviour 3, Suppl. I, 3-1 3.

Baskin, D. G., Stein, L. J., Ikeda, H., Woods, S. C., Figlewicz, D. P., Porte, D., Greenwood, M. R. C. \& Dorsa, D. M. (1985). Life Sciences 36, 627-634.

Bereiter, D. A. \& Jeanrenaud, B. (1979). Brain Research $16.5,249-260$.

Berthoud, H.-R. \& Jeanrenaud, B. (1979). Endocrinology 105, $146-151$.

Bray, G. A. (1982). Proceedings of the Nutrition Society 4I, 95-108.

Bray, G. A. (1984). Clinics in Endocrinology and Metabolism 134, 521-546.

Bray, G. A. (1985). International fournal of Obesity 9, Suppl. I, I19-137.

Bray, G. A. \& Nishizawa, Y. (1982). Nature 294, 900-902.

Bray, G. A., Sclafani, A. \& Novin, D. (I982). American Fournal of Physiology 2, R445-R449.

Bray, G. A. \& York, D. A. (197I). Physiological Reviews 51, 598-646.

Bray, G. A. \& York, D. A. (1979). Physiological Reviews 59, 719-809.

Brown, M. (1981). Diabetologia 20, 299-304.

Bruce, B. K., King, B. M., Phelps, G. R. \& Veita, M. C. (1982). American Journal of Physiology 243, E $_{152}-E_{157}$.

Castonguay, T. W., Hartman, W. J., Fitzpatrick, E. A. \& Stern, J. S. (1982). Journal of Nutrition $112,796-800$.

Cattabeni, F., Maggi, A., Morduzzi, M., Da Angelis, L. \& Racogni, G. (1978). Fournal of Neurochemistry 31, 565-567.

Coscina, D. V. \& Nobrega, J. N. (1984). International fournal of Obesity 8, Suppl. I, 191-200.

Cruce, J. A. E., Thoa, N. B. \& Jacobowitz, D. M. (1976). Brain Research 101, $165^{-1} 70$.

Dockray, G. J. (1987). Proceedings of the Nutrition Society 46, $119-124$.

Dunmore, S. \& Beloff-Chain, A. (1982). Fournal of Endocrinology 92, 1 $5^{-21}$.

Feldman, J. \& Henderson, J. (1978). Diabetes 27, 389-395.

Figlewicz, D. P., Dorsa, D. M., Stein, L. J., Baskin, D. G., Paquette, T., Greenwood, M. R. C.. Woods, S. C. \& Porte, D. (1985). Endocrinology $117,1537-1543$.

Finkelstein, J. \& Steggles, A. W. (1981). Peptides 2, 19-21.

Garattini, S. \& Samanin, R. (1984). International Yournal of Obesity 8, Suppl. 1, $151-158$. 
Garthwaite, T. L., Kalkhoff, R. K., Guansgin, A. R., Hagen, T. C. \& Menhan, L. A. (1979). Endocrinology $105,1178-1182$.

Gibson, M. J., Liotta, A. S. \& Krieger, D. T. (1981). Neuropeptides 1, 349-362.

Gold, R. M. (1970). Physiology and Behaviour 5, 23-25.

Goldman, C., Marino, L. \& Liebowitz, S. F. (1985). European Fournal of Pharmacology 115, II-I 19.

Gordon, C. J. \& Heath, J. E. (1981). Peptides 2, 397-401.

Gordon, C. J. Rezvani, A. H. \& Heath, J. E. (I984). Neuroscience and Behaviour Reviews 8, $73^{-82 .}$

Govoni, S. \& Yang, H.-Y. T. (1981). Fournal of Neurochemistry 36, 1829-1833.

Grossman, S. P. (1962). American Yournal of Physiology 292, 872-882.

Gunion, M. W. \& Peters, R. H. (1981). American fournal of Physiology 241, R I3-R 184.

Han, P. N., Lin, C. H., Mu, J. Y. \& Liu, A.-C. (1965). American Fournal of Physiology 209, $627-631$.

Han, P. W. (1968). American fournal of Physiology $215,1343^{-1} 350$.

Hansky, J. \& Ho, P. (1979). Australian fournal of Experimental Biology and Medical Science 57, 575-579.

Hawkins, M. F. (1986). Physiology and Behaviour 36, 1-8.

Holt, S. J., Wheal, H. \& York, D. A. (1985). Proceedings of the Nutrition Society 44, 124 A.

Hughes, S. J. \& York, D. A. (1983). Hormone and Metabolic Research 15, 335-339.

Hyslop, P. \& York, D. A. (1980). Biochemical and Biophysical Research Communications 92, 8 I9-824.

Ikeda, H., Nishikawa, Y. \& Matsuo, T. (1 980). American fournal of Physiology 239, 379-384.

Inoue, S. \& Bray, G. A. (1977). Endocrinology 100, 108-114.

Inoue, S., Bray, G. A. \& Mullen, Y. T. S. (1978). American foumal of Physiology 235, $\mathrm{E}_{266}$-E271.

Jhanwar-Uniyal, M., Roland, C. R. \& Leibowitz, S. F. (1985). Life Sciences 38, 473-482.

Kimura, H. \& Kutiyama, K. (1975). Journal of Neurochemistry 24, 903-907.

King, B. M., Castellanos, F. X., Kastin, A. J., Berzas, C., Mauk, D., Olson, G. A. \& Olson, R. D. (1979). Pharmacology, Biochemistry and Behaviour I1, 729-732.

Knehans, A. W. \& Rosmos, D. R. (1982). American fournal of Physiology 242, E253-E261.

Knehans, A. W. \& Rosmos, D. R. (1983). American Fournal of Physiology 244, E567-E.574.

Kulkosky, P. J., Breckenridge, C., Krinsky, R. \& Woods, S. C. (1976). Behavioural Biology 18, 227-234.

Le Magnen, J. (1983). Physiological Reviews 63, 314-386.

Levin, B. E. \& Sullivan, A. C. (1979a). Phurmacology, Biochemistry and Behaviour 11, 77-82.

Levin, B. E. \& Sullivan, A. C. (1979b). Brain Research $171,560-566$.

Levin, B. E., Triscari, J. \& Sullivan, A. C. (1982). American fournal of Physiology 243, Ri $70-R_{178 .}$

Liebowitz, S. F. (1978). Pharmacology, Biochemistry and Behaviour 8, 163-1 75.

Leibowitz, S. F., Roland, C., Hor, L. \& Skuillari, V. (1982). Physiology and Behaviour 32, $857-864$.

Ljunberg, T. \& Ungerstedt, U. (1976). Physiology and Behaviour 16, 277-283.

Lorden, J. F., Oltmans, G. A. \& Margules, D. L. (1975). Brain Research 96, 390-394.

Lorden, J. F., Oltmans, G. A. \& Margules, D. L. (1976). Brain Research $117,357-36$ r.

McLaughlin, C. L. \& Baile, C. A. (1978). Pharmacology, Biochemistry and Behaviour 10, 87-93.

McLaughlin, C. L. \& Baile, C. A. (1980). Physiology and Behaviour 25, 341-346.

McLaughlin, C. L. \& Baile, C. A. (1981). Physiology and Behaviour 26, 433-437.

McLaughlin, C. L. \& Baile, C. A. (1984). Physiology and Behaviour 32, 929-933.

McLaughlin, C. L. \& Baile, C. A. (1985). Physiology and Behaviour 35, 365-370.

Marchington, D., Rothwell, N. J., Stock, D. J. \& York, D. A. (1983). Fournal of Nutrition I13, I395-I 402.

Margules, D. L., Moisset, B., Lewis, M., Shibuyz, H. \& Pert, C. (1978). Science 202, 988-993.•

Matsumura, M., Yumanoi, A., Sato, K., Tsuda, M., Chitamori, K. \& Saito, S. (I984). Hormone and Metabolic Research 16, $105^{-106 .}$

Morley, J. E. (1980). Life Sciences 27, 355-368.

Morley, J. E. \& Levine, A. S. (1983). Lancet i, 398-40r.

Nemeroff, C. B., Visette, G. \& Kizer, S. J. (1978). Brain Research 146, 385-387. 
Niijima, A., Rohner-Jeanrenaud, F. \& Jeanrenaud, B. (1984). American Journal of Physiology 247 , R650-R654.

Nishizawa, Y. \& Bray, G. A. (1978). Journal of Clinical Investigation 6r, 714-721.

Oku, J., Inoue, S., Glick, S., Bray, G. \& Walsh, J. M. (1984). International fournal of Obesity 8, I $71-182$.

Oomura, Y., Ohta, M., Ishibashi, S., Kita, H., Obajima, T. \& Ono, T. (1978). In Recent Advances in Obesity Research, vol. 2, pp. 17-26 [G. A. Bray, editor]. London: John Libbey.

Opsahl, C. A. \& Powley, T. L. (1974). American fournal of Physiology 226, 34-38.

Orosco, M., Jacquot, C. \& Cohen, Y. (1981). General Pharmacology 12, 267-271.

Panksepp, J. \& Meeker, R. B. (1980). Brain Research Bulletin 5, Suppl. 2, 453-460.

Patel, Y., Cameron, D. P., Stefan, Y., Malaise-Lagal, F. \& Orci, L. (1977). Science 198, 930-931.

Perkins, M. N., Rothwell, N. J., Stock, M. J. \& Stone, T. W. (198I). Nature 289, $401-402$.

Pollard, H., Lorens, C., Schwartz, J. C., Gras, C. \& Dray, F. (1978). Brain Research I51, 392-398.

Porte, D. \& Woods, S. C. (1981). Diabetologia 20, 274-278.

Powley, T. L. (1977). Psychological Reviews 84, 89-126.

Powley, T. L. \& Opsahl, C. A. (1974). American Journal of Physiology 226, 25-33.

Rappaport, E., Young, J. B. \& Landsberg, L. (1982). Endocrinology I 10, 650-656.

Recant, L., Voyles, N. R., Luciano, M. \& Pert, C. B. (I980). Peptides I, 309-31 3.

Recant, L., Voyles, N., Wade, A., Awobe, S. \& Bhathena, S. J. (I983). Hormone and Metabolic Research $15,589-593$.

Rohner-Jeanrenaud, F., Hochstrasser, A.-C. \& Jeanrenaud, B. (1983). American foumal of Physiology 244, $\mathrm{E}_{31} 1-\mathrm{E}_{322}$.

Rossier, J., Rogers, J., Shibasaki, R., Guilleman, R. \& Bloom, F. E. (1979). Proceedings of the National Academy of Science, USA 76, 2077-2080.

Rostene, W. H., Bazin, R., Morgat, J. L. Dussaillant, M. \& Broer, Y. (1985). Hormone and Metabolic Research 17, 692-693.

Rothwell, N. J. \& Stock, M. J. (1981). Pflügers Archiv 392, 172-1 77.

Sahabian, B. J., Trayhurn, P., Wallace, M., Deeley, R., Winn, P., Robbins, T. W. \& Everitt, B. J. ( $\mathrm{I}_{83}$ ). Neuroscience Letters $39,32 \mathrm{I}-326$.

Saito, M. \& Bray, G. A. (1984). American Yournal of Physiology 15, R20-R25.

Saito, A., Williams, J. \& Goldfine, I. (1981). Nature 289, 599-600.

Schneider, B., Monahan, J. \& Hirsch, J. (1979). Fournal of Clinical Investigation 64, 1348-1356.

Sclafani, A. \& Berner, C. N. (1977). Fournal of Comparative and Physiological Psychology 91, $1000-1018$.

Sena, A. G., Rebel, G., Bieth, R., Hubert, P. \& Waksman, A. (1982). Biochimica et Biophysica Acta 710, 290-296.

Sheppard, M. C., Bailey, C. J., Flatt, P. R., Swanson-Flatt, S. K. \& Shennan, K. I. (1985). Acto Endocrinologica 108, 532-536.

Silverstone, T. \& Goodall, E. (1984). International fournal of Obesity 8, Suppl. 1, 23-34.

Stellar, E. (1954). Psychological Reviews 61, 5-22.

Strauss, E. \& Yallow, R. S. (1979). Science 203, 68-69.

Stricker, E. M. \& Zigmond, M. J. (1984). International fournal of Obesity 8, Suppl. 1. 39-50.

Tews, J. K. (1981). Life Sciences 29, 2535-2542.

Van der Kroon, P. \& Speijers, J. A. (1979). Metabolism 28, 1-3.

Van der Tuig, J. G., Kerner, J. \& Romsos, D. R. (1985). American fournal of Physiology 248, E607-E6r7.

Van der Tuig, J. G., Knehans, A. W. \& Romsos, D. R. (1982). Life Sciences 30, 91 3-920.

Voyles, N. R., Awoke, S., Wade, A., Bhathena, S. J., Smith, S. S. \& Recant, L. (1982). Hormone and Metabolic Research 14, 392-395.

Wexler, B. C. \& McMurtry, J. P. (1985). International Journal of Obesity 9, 77-9I.

Woods, S., West, D., Stein, L., McKay, L., Lotter, E., Porte, S., Kenney, N. \& Porte, D. (1981). Diabetologia 20, 305-313.

York, D. A. (1985). Proceeding of the Nutrition Society 44, $189-200$.

York, D. A., Holt, S. J. \& Marchington, D. (1985). International fournal of Obesity 9, Suppl. 2, $89-96$.

York, D. A., Hyslop, P. A. \& French, R. (1982). Biochemical and Biophysical Research Communications 106, $147^{-1}-183$. 
York, D. A., Marchington, D., Holt, S. J. \& Allars, J. (1985). American fournal of Physiology 249 , E299-E305.

Yoshida, T. \& Bray, G. A. (1984). American Fournal of Physiology 246, R558-R565.

Yoshida, T., Kenmetz, J. W. \& Bray G. A. (1983). Fournal of Clinical Investigation 72, 919-927.

Yoshimatsu, H., Oomura, Y., Katafuchi, T., Niijima, A. \& Sato, A. (1985). Brain Research 339, $390-392$.

Young, J. B. \& Landsberg, L. (1980). Fournal of Clinical Investigation 6, 1086-1094.

Young, J. B. \& Landsberg, L. (1983). American fournal of Nutrition 245, E $148-\mathrm{E}_{1} 54$.

Yukimura, Y. \& Bray, G. A. (1978). Endocrine Research Communications 5, 189-198.

Yukimura, Y., Bray, G. A. \& Wolfsen, A. R. (1978). Endocrinology r03, 1924-1928.

Zaror-Behrens, G. \& Himms-Hagen, J. (1983). American fournal of Physiology 244, E36r-E 366. 